\title{
Frequency of Dermatological Disorders Associated with Hepatitis C Virus Infection in Sharkia Governorate, Egypt
}

\author{
Kamal A Amer ${ }^{1}$, Marawan N El Gohary ${ }^{2}$ \\ and Fathia M Kattab ${ }^{3}$ \\ Departments of Tropical Medicine ${ }^{1}$, Internal Medicine ${ }^{2}$ and Dermatology \& Venorology, \\ Faculty of Medicine, Zagazig University, Zagazig, Egypt.
}

Corresponding Author Kamal A. Amer

Mobile:

$+201226204876$

E mail:

drkamalamer82@

yahoo.com

Key words:

Chronic hepatitis $C$;

skin manifestations;

lichen planus;

urticarial; vitiligo;

mixed

cryoglobulinemia
Background and study aim: Egypt has the highest HCV prevalence in the world. Cutaneous lesions are found in some patients of HCV infection. This study was conducted to determine frequency and types of dermatological disorders present in chronic $\mathrm{HCV}$ infection in Sharkia governorate, Egypt.

Patients and Methods: 157 Patients of chronic hepatitis $\mathrm{C}$ divided into 2 groups; group 1: Includes 117 patients with chronic HCV infection who didn't receive antiviral treatment group 2: Includes 40 patients with chronic HCV infection who received antiviral treatment (peg- interferon and ribavirin). Detailed history taking, clinical and dermatological examination was carried out. Biochemical profile including complete blood count, platelet count, and cryoglobulins were done.
Results: The percentage of dermatological manifestations increase with the severity of liver cirrhosis. Pruritus was the predominant dermatological manifestation in untreated and treated patients $(37.9 \%)$ and $(52.9 \%)$ respectively. There was significant statistical difference between positive and negative cryoglobulineamic patients in the untreated group regarding different dermatological manifestations with high percentage of pruritus, vasculitis and purpura in patients with cryoglobulin positivity $(p=0.04)$.

Conclusion: Skin manifestations are present in $61 \%$ of chronic $\mathrm{HCV}$ patients and less frequent in treated group. The frequency of skin manifestations increases with the advancement of liver disease. Pruritis is the most frequent manifestation in all patients.

\section{INTRODUCTION}

Although the hepatitis $\mathrm{C}$ virus ( $\mathrm{HCV}$ ) was identified only in 1989 , it has emerged as major cause not only of liver disease, but also of numerous extrahepatic conditions [1]. According to different studies, 40-74\% of patients infected with HCV might develop at least one extrahepatic manifestation during the course of the disease [2,3]. In fact as many as $17 \%$ to $46 \%$ of all $\mathrm{HCV}-$ infected patients have at least one skin manifestation $[\mathbf{2 , 4}]$. This study was conducted to determine frequency and types of dermatological disorders present in chronic HCV infection in Sharkia governorate, Egypt.

\section{PATIENTS AND METHODS}

Study design: Cross sectional study
Site and Time of study: This study was carried out in Tropical Medicine, Internal Medicine Departments and Dermatology outpatient clinic, Zagazig University Hospitals in the period from August 2016 to August 2017.

Patients: The sample size was 157 patients, which were divided into two groups: group (I): Includes 117 patients with chronic HCV infection who didn't receive antiviral treatment (79 patients with skin manifestations and 38 patients without skin manifestations). Group(II): Includes 40 patients with chronic HCV infection who received anti viral treatment (peg interferon and ribavirin) (17 patients with skin manifestations and 23 patients without skin manifestations).all patients in the second group received antiviral treatment before the year 2015 . 
Inclusion criteria: All patients with chronic liver disease due to $\mathrm{HCV}$ either on treatment or not. The drugs used for treatment of chronic $\mathrm{HCV}$ were pegylated interferon and ribavirin.

Exclusion criteria: Any patient with: hepatitis $\mathrm{B}$ or auto immune hepatitis or diabetes mellitus or renal failure or diagnosed malignancy, were excluded from the study.

\section{Patient assessment}

All patients of the study were subjected to the following:

1- Complete history taking: History of present dermatological disease including: onset, course, duration, site, and its relation to antiviral treatment in the second group.

2- Full clinical examination: general examination. Full dermatological examination of the present lesion as regard site, size, and shape was done.

3- Routine Laboratory investigations including: complete blood picture, Liver profile tests, Kidney function tests, Coagulation profile (PT, INR).

4- Child-Turcotte-Pugh classification.

5- Imaging studies included: Pelvi-abdominal ultrasonography.

6- Specific investigation :

- Anti HCV antibodies: Using $4^{\text {th }}$ generation ELISA.

- Cryoglobulines.

- HCV-RNA; using polymerase chain reaction (PCR) and viral load were classified into:

- Mild viremia $<100,000 \mathrm{Iu} / \mathrm{ml}$.

- Moderate viremia 100,000-1,000,000Iu/ml.

- Severe viremia $>1,000,000 \mathrm{Iu} / \mathrm{ml}$.

7- Recording and photographing of any dermatological disease.

\section{Statistical Analysis}

All data were collected, tabulated and statistically analyzed using SPSS 20.0 for windows (SPSS Inc., Chicago, IL, USA). Quantitative data were expressed as the mean \pm SD \& median (range), and qualitative data were expressed as absolute frequencies (number) and relative frequencies (percentage). Independent samples Student's ttest was used to compare between two groups of normally distributed variables while Mann Whitney U test was used for non- normally distributed variables. Paired $\mathrm{t}$ was used to compare between two paired groups. Percent of categorical variables were compared using Chisquare test or Fisher's exact test or Mcnemar test when appropriate. All tests were two sided. P- value $<0.05$ was considered statistically significant (S) and $\mathrm{p}$-value $\geq 0.05$ was considered statistically insignificant (NS).

\section{RESULTS}

There was no statistically significant difference between both groups regarding sex distribution, while the treated patients were significantly younger than the untreated group. There was a highly statistically significant difference between both groups regarding duration of illness $(p<0.001)$, while there were no significant statistical differences between them regarding pruritus and fall of hair (Table 1). There was a highly statistical significant difference between both groups regarding liver and spleen size, presence of ascites, skin manifestations and Child Pugh classes $(\mathrm{p}<0.001)($ Table 1$)$.

Pruritus was the predominant dermatological manifestation in untreated and treated patients $(37.9 \%)$ and $(52.9 \%)$ respectively regarding all skin manifestations (Table 2).

There was significant statistical difference between all patients regarding their dermatological manifestations and the severity of the liver disease by Child Pugh class $(\mathrm{P}<0.05)$. The percentage of dermatological manifestations increases with the advancement of the severity of liver cirrhosis (Table 3).

There were no statistically significant difference between all patients with or without skin manifestation as regard viral load, degree of viraemia and cryoglobulin $(\mathrm{P}>0.05)$ (Table 4).

Pruritus, hair falling, vasculitis, oral lichen planus, alopecia and purpura occur more frequently in patients with severe viraemia (Table 5).

The common skin lesions in untreated patients with positive cryoglobulin were purpura, pruritus and vasculitis while with negative cryoglobulin were hair falling, psoriasis and lichen planus (Table 6).

The common skin lesions in treated patients with positive cryoglobulin were present in patients with vitiligo and pruritus while with negative cryoglobulin was lichen planus and alopecia (Table 7). 
Table (1): Demographic, clinical, ultrasonographic, child classification of both groups

\begin{tabular}{|c|c|c|c|}
\hline 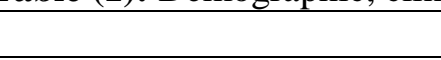 & Group I (N=117) & Group II (N=40) & P value \\
\hline Mean age (years) & $52.79 \pm 11.53$ & $40.07 \pm 6.51$ & $<0.001(\mathrm{HS})$ \\
\hline Gender(male/female) & $67 / 50$ & $27 / 13$ & $0.25(\mathrm{NS})$ \\
\hline Duration of illness (years) & $8.14 \pm 4.09$ & $4.75 \pm 2.58$ & $<0.001(\mathrm{HS})$ \\
\hline Pruritus & $30(25.6)$ & $9(22.5)$ & $0.69(\mathrm{NS})$ \\
\hline Fall of hair & $8(6.8)$ & $0(0)$ & $0.08(\mathrm{NS})$ \\
\hline Skin lesions & $79(67.5)$ & $17(42.5)$ & $0.001(\mathrm{HS})$ \\
\hline \multicolumn{4}{|l|}{ U.S. finding } \\
\hline \multirow{3}{*}{$\begin{aligned} & \text { Liver size: } \text { Average } \\
& \text { Enlarged } \\
& \text { Shrunken }\end{aligned}$} & 25 & 32 & \multirow{3}{*}{$<0.001(\mathrm{HS})$} \\
\hline & 34 & 8 & \\
\hline & 58 & 0 & \\
\hline Enlarged spleen & 81 & 6 & $<0.001(\mathrm{HS})$ \\
\hline Ascites & 64 & 0 & $<0.001(\mathrm{HS})$ \\
\hline \multicolumn{4}{|l|}{ Child Pugh classification } \\
\hline $\mathbf{A}$ & $48(41)$ & $40(100)$ & \multirow{3}{*}{$<0.001(\mathrm{HS})$} \\
\hline B & $49(41.9)$ & $0(0)$ & \\
\hline $\mathbf{C}$ & $20(17.1)$ & $0(0)$ & \\
\hline
\end{tabular}

HS; highly significant, NS; non-significant

Table (2): Comparison between treated and untreated patients with different skin manifestations regarding frequency and type

\begin{tabular}{|c|c|c|c|c|c|}
\hline & \multicolumn{2}{|c|}{$\begin{array}{c}\text { Untreated patients } \\
\text { with dermatological } \\
\text { manifestations }(\mathrm{N}=79) \\
\text { No } \quad \%\end{array}$} & \multicolumn{2}{|c|}{$\begin{array}{l}\text { Treated patients with } \\
\text { dermatological } \\
\text { manifestations }(\mathrm{N}=17)\end{array}$} & $\begin{array}{c}\text { Test of } \\
\text { significance }\end{array}$ \\
\hline Pruritus & 30 & $37.9 \%$ & 9 & $52.9 \%$ & \multirow{13}{*}{$\begin{array}{c}2=23.490 \\
\mathrm{P}=0.064(\mathrm{NS})\end{array}$} \\
\hline Hair falling & 8 & $10.1 \%$ & 0 & $0 \%$ & \\
\hline Urticaria & 6 & $7.5 \%$ & 0 & $0 \%$ & \\
\hline Vasculitis & 5 & $6.3 \%$ & 0 & $0 \%$ & \\
\hline Lichen (oral) & 5 & $6.3 \%$ & 1 & $5.9 \%$ & \\
\hline Dry skin & 5 & $6.3 \%$ & 0 & $0 \%$ & \\
\hline Alopecia & 5 & $6.3 \%$ & 5 & $29.4 \%$ & \\
\hline Spider navi & 4 & $5.1 \%$ & 0 & $0 \%$ & \\
\hline Vitiligo & 4 & $5.1 \%$ & 1 & $5.9 \%$ & \\
\hline Psoriasis & 3 & $3.7 \%$ & 0 & $0 \%$ & \\
\hline Erythema Multiform & 2 & $2.5 \%$ & 0 & $0 \%$ & \\
\hline Purpura & 1 & $1.2 \%$ & 0 & $0 \%$ & \\
\hline Lichen (cutaneous) & 1 & $1.2 \%$ & 1 & $5.9 \%$ & \\
\hline NS non significant & & $2=$ & square $\mathrm{t}$ & & \\
\hline
\end{tabular}

Table (3): Relationship between severity of liver cirrhosis (by Child Pugh class) and presence of dermatological manifestations in all patients

\begin{tabular}{|c|c|c|c|c|c|c|c|}
\hline \multirow{2}{*}{$\begin{array}{l}\qquad \text { Child Pugh class } \\
\text { Dermatological } \\
\text { manifestations }\end{array}$} & \multicolumn{2}{|c|}{$\underset{(\mathbf{N}=\mathbf{8 8})}{\mathrm{A}}$} & \multicolumn{2}{|c|}{$\begin{array}{c}B \\
(\mathrm{~N}=49)\end{array}$} & \multicolumn{2}{|c|}{$\begin{array}{c}\mathrm{C} \\
(\mathrm{N}=20)\end{array}$} & \multirow[t]{2}{*}{$\begin{array}{c}\text { Test of } \\
\text { significance }\end{array}$} \\
\hline & No & $\%$ & No & $\%$ & No & $\%$ & \\
\hline Absent & 42 & $47.7 \%$ & 14 & $28.5 \%$ & 5 & $25 \%$ & \multirow{2}{*}{$\begin{array}{c}2=6.71 \\
P=0.035 \\
(S)\end{array}$} \\
\hline Present & 46 & $52.2 \%$ & 35 & $71.5 \%$ & 15 & $75 \%$ & \\
\hline
\end{tabular}


Table (4): Comparison between patients with and without skin manifestations as regard HCV RNA, degree of viremia and cryoglobulin

\begin{tabular}{|c|c|c|c|c|}
\hline & & $\begin{array}{l}\text { Patients with } \\
\text { skin } \\
\text { manifestations } \\
(\mathrm{N}=96)\end{array}$ & $\begin{array}{c}\text { Patients } \\
\text { without skin } \\
\text { manifestations } \\
(\mathbf{N}=61)\end{array}$ & \multirow{3}{*}{$\begin{array}{c}\begin{array}{c}\text { Test of } \\
\text { significance }\end{array} \\
\mathrm{U}=-0.495 \\
\mathrm{P}=0.428(\mathrm{NS}) \\
2=1.110\end{array}$} \\
\hline \multicolumn{2}{|c|}{ HCV RNA $\left(\times 10^{6} / \mathrm{ml}\right)$ Mean \pm SD } & $1.28 \pm 1.18$ & $1.38 \pm 1.30$ & \\
\hline Deoree of & Mild No (\%) & $4(4.2)$ & $2(3.3)$ & \\
\hline Cryoglobulin & $\begin{array}{l}\text { Moderate No (\%) } \\
\text { Severe No }(\%) \\
\text { Negative No }(\%) \\
\text { Positive No }(\%)\end{array}$ & $\begin{array}{l}39(40.6) \\
53(55.2) \\
52(54.2) \\
44(45.8)\end{array}$ & $\begin{array}{l}30(49.2) \\
29(47.5) \\
34(55.7) \\
27(44.3)\end{array}$ & $\begin{array}{c}2=0.037 \\
\mathrm{P}=0.847(\mathrm{NS})\end{array}$ \\
\hline
\end{tabular}

NS non significant

$\mathrm{U}=$ Mann-Whitney U test

2=Chi-square test

Table (5): Relationship between degree of HCV viraemia and different dermatological manifestations in all patients

\begin{tabular}{|c|c|c|c|c|c|c|c|}
\hline \multirow{2}{*}{$\begin{array}{l}\text { Degree of HCV } \\
\text { Viraemia } \\
\text { Type of dermatological } \\
\text { manifestations } \\
\begin{array}{l}\text { Pruritus } \quad(\mathrm{N}=39) \\
\\
\end{array} \quad \mathrm{No}(\%)\end{array}$} & \multicolumn{2}{|c|}{$\begin{array}{l}\text { Mild } \\
(\mathbf{N}=4)\end{array}$} & \multicolumn{2}{|c|}{$\begin{array}{l}\text { Moderate } \\
(\mathrm{N}=39)\end{array}$} & \multicolumn{2}{|c|}{$\begin{array}{l}\text { Severe } \\
(\mathrm{N}=53)\end{array}$} & \multirow{12}{*}{$\begin{array}{c}\begin{array}{c}\text { Test of } \\
\text { significance }\end{array} \\
2=36.160 \\
P=0.019(\mathrm{~S})\end{array}$} \\
\hline & 0 & $0 \%$ & 14 & $\begin{array}{c}35.8 \% \\
\%\end{array}$ & 25 & $64.1 \%$ & \\
\hline $\begin{array}{r}\text { Hair falling }(\mathbf{N}=8) \\
\operatorname{No}(\%)\end{array}$ & 0 & $0 \%$ & 3 & $37.5 \%$ & 5 & $62.5 \%$ & \\
\hline $\begin{array}{ll}\text { Urticaria } & (\mathrm{N}=6) \\
\mathrm{No}(\%)\end{array}$ & 2 & $33.3 \%$ & 3 & $50 \%$ & 1 & $16.7 \%$ & \\
\hline $\begin{array}{r}(\mathrm{N}=5) \\
\text { No(\%) }\end{array}$ & 0 & $0 \%$ & 0 & $0 \%$ & 5 & $100 \%$ & \\
\hline $\begin{aligned} \text { Lichen (oral) }(\mathrm{N}=6) \\
\mathrm{No}(\%)\end{aligned}$ & 0 & $0 \%$ & 2 & $25 \%$ & 4 & $75 \%$ & \\
\hline $\begin{array}{ll}\text { Dry skin } & (\mathrm{N}=5) \\
& \mathrm{No}(\%) \\
\text { Alopecia } & (\mathrm{N}=10) \\
& \mathrm{No}(\%)\end{array}$ & 0 & $40 \%$ & 1 & $20 \%$ & 2 & $40 \%$ & \\
\hline $\begin{array}{r}\text { Spider navi }(\mathrm{N}=4) \\
\text { No(\%) }\end{array}$ & 0 & $0 \%$ & 2 & $50 \%$ & 2 & $50 \%$ & \\
\hline $\begin{array}{lr}\text { Vitiligo } & (\mathrm{N}=5) \\
& \mathrm{No}(\%)\end{array}$ & 0 & $0 \%$ & 5 & $100 \%$ & 0 & $0 \%$ & \\
\hline \begin{tabular}{lr} 
Psoriasis & $(\mathrm{N}=3)$ \\
& No(\%) \\
\multicolumn{2}{c}{ Erythema multiform } \\
$(\mathrm{N}=2)$ & \\
& $\mathrm{No}(\%)$
\end{tabular} & 0 & $0 \%$ & 2 & $\begin{array}{l}66.7 \% \\
100 \%\end{array}$ & 1 & $\begin{array}{c}33.3 \% \\
0 \%\end{array}$ & \\
\hline $\begin{array}{r}(\mathrm{N}=1) \\
\mathrm{No}(\%) \\
\end{array}$ & 0 & $0 \%$ & 0 & $0 \%$ & 1 & $100 \%$ & \\
\hline $\begin{array}{lr}\text { Lichen (cutaneous) } \\
(\mathrm{N}=2) & \mathrm{No}(\%) \\
\end{array}$ & 0 & $0 \%$ & 1 & $50 \%$ & 1 & $50 \%$ & \\
\hline
\end{tabular}

S significant

$2=$ Chi-square test 
Table (6): Relationship between cryoglobulin and different skin lesions in untreated patients

\begin{tabular}{l|c|c|c|c|c|}
\hline \multicolumn{1}{|c|}{ Cryoglobulin } & \multicolumn{2}{|c|}{$\begin{array}{c}\text { Negative } \\
\text { (N=45) }\end{array}$} & \multicolumn{2}{c|}{$\begin{array}{c}\text { Positive } \\
\text { (N=34) }\end{array}$} & $\begin{array}{c}\text { Test of } \\
\text { significance }\end{array}$ \\
$\begin{array}{l}\text { Type of dermatological } \\
\text { manifestations }\end{array}$ & No & $\%$ & No & $\%$ & \\
\hline Pruritus (N=30) & 10 & 33.3 & 20 & 66.7 & \\
Hair falling (N=8) & 8 & 100 & 0 & 0 & $2=22.52$ \\
Urticaria (N=6) & 5 & 83.3 & 1 & 16.6 & $\mathrm{P}=0.041(\mathrm{~S})$ \\
Vasculitis (N=5) & 2 & 40 & 3 & 60 & \\
Lichen (oral) (N=5) & 4 & 80 & 1 & 20 & \\
Dry skin (N=5) & 3 & 60 & 2 & 40 & \\
Alopecia (N=5) & 3 & 60 & 2 & 40 & \\
Spider navi (N=4) & 2 & 50 & 2 & 50 & \\
Vitiligo (N=4) & 3 & 75 & 1 & 25 & \\
Psoriasis (N=3) & 3 & 100 & 0 & 0 & \\
Erythema multiform (N=2) & 1 & 50 & 1 & 50 & \\
Purpura (N=1) & 0 & 0 & 1 & 100 & \\
Lichen (cutaneous) (N=1) & 1 & 100 & 0 & 0 & \\
S significant & & & $2=$ Chi-square test
\end{tabular}

Table (7): Relationship between cryoglobulin and different skin lesions in treated patients

\begin{tabular}{l|cc|cc|c|}
\hline \multicolumn{1}{|c|}{ Cryoglobulin } & \multicolumn{2}{|c|}{$\begin{array}{c}\text { Negative } \\
\text { (N=7) }\end{array}$} & \multicolumn{2}{c|}{$\begin{array}{c}\text { Positive } \\
\text { (N=10) }\end{array}$} & $\begin{array}{c}\text { Test of } \\
\text { significance }\end{array}$ \\
manifestations & No & $\%$ & No & $\%$ & \\
\hline Pruritus (N=9) & 3 & 25 & 6 & 75 & $2=3.789$ \\
Alopecia (N=5) & 2 & 40 & 3 & 60 & $\mathrm{P}=0.435$ (NS) \\
Lichen (oral) (N=1) & 1 & 100 & 0 & 0 & \\
Vitiligo (N=1) & 0 & 0 & 1 & 100 & \\
Lichen (cutaneous) (N=1) & 1 & 100 & 0 & 0 & \\
NS non significant & \multicolumn{2}{|c|}{ 2=Chi-square test }
\end{tabular}

\section{DISCUSSION}

Hepatitis $\mathrm{C}$ virus is one of the most common causes of chronic hepatitis. It is frequently associated with extrahepatic manifestations such as mixed cryoglobulinemia, neurological, dermatological, and renal complications [5-7].

Various types of skin lesions have been reported due to HCV infection, as well as anti-HCV treatment. Some skin lesions improve with antiHCV treatment, whereas others worsen, necessitating the discontinuation of the treatment [8].

This study was designed to assess the frequency of dermatological manifestations associated with chronic HCV infection and its treatment. To reach this purpose, 157 patients with chronic $\mathrm{HCV}$ infection were recruited. They were divided into
2 groups, the first included 117 patients who didn't receive anti-HCV treatment and the second included 40 patients who received treatment in the form of peg-interferon and ribavirin before the year 2015 .

In this study, the treated patients were significantly younger than the untreated patients. This may be due to the significantly longer duration of illness of untreated group that exposes the patients to decompensation making them non-candidates for treatment. There was no statistically significant difference between both groups regarding sex distribution and this is in agreement with Asim and Wahid and Ali et al. $[9,10]$.

All the parameters of clinical examination were significantly pointing to the advanced disease, higher Child classes and more frequent skin 
manifestations in the untreated group. Raslan et al. reported that shrunken liver, splenomegaly and ascites all are risk factors significantly associated with skin manifestations in chronic $\mathrm{HCV}$ patients. In this study, $75 \%$ of patients with Child C class had skin manifestations [4].

In the current study, $61 \%$ of all patients had skin manifestations. Other Egyptian studies reported comparable results; $46 \%$ in Cairo [4] and $64 \%$ in Al-Mansoura [11] while, it was reported to be $80 \%$ and $88 \%$ in Turkey and Pakistan respectively $[10,12]$. This difference may be due to viral genotype, genetic or racial differences. In addition, the apparent protective role of Schistosoma mansoni coinfection against the development of immunemediated diseases such as mixed cryglobulinemia; which has a role in development of skin manifestations may participate in these different results [13]. Also, helminthic infections are characterized by a strong $\mathrm{T}$ helper- 2 response and down-regulated immune system which are both beneficial in protecting the host from developing autoimmune diseases and/or relieving symptoms of an established autoimmune disease [14].

Pruritus was the most frequent symptom in all patients with skin manifestations (41\%). This finding is in agreement with Asim and Wahid and Ali et al. who reported that pruritus is the commonest skin manifestation among $\mathrm{HCV}$ patients representing $40 \%$ and $35 \%$ respectively $[9,10]$. Moreover, its frequency was greater in treated $(52.9 \%)$ than untreated $(37.9 \%)$ group. Also Morsy et al. reported $45 \%$ and $14 \%$ in treated and untreated groups respectively [11]. Interferon and ribavirin regimens were associated with new onset of significant pruritus in more than $10 \%$ of patients [15]. In this context, ribavirin was the most important cause responsible for rash and pruritus. With the advent of new anti$\mathrm{HCV}$ regimens free of interferon and ribavirin, rash and pruritus are no longer important complications of HCV treatment [16].

In addition to pruritus, alopecia also was more frequent in treated than untreated group $(29.4 \%$ versus $6.3 \%$ ) and this is going with the studies which reported alopecia as a side effect of antiviral therapy $[\mathbf{1 7}, \mathbf{1 8 , 1 9 ]}$.

In this study, $7.5 \%$ of untreated patients had urticaria, Asim and Wahid and Morsy et al. reported $6 \%$ and $2.4 \%$ respectively $[\mathbf{9 , 1 0}]$. Whether hepatitis $\mathrm{C}$ infection causes urticaria and the related etiopathogenic process remains unclear. Siddique et al. and Kanazawa et al. reported a positive relation between $\mathrm{HCV}$ and urticaria [20,21], while other studies deny this relation [22,23]. Dega et al. stated that $18 \%$ of patients with urticaria had HCV antibodies [24] and Kanazawa et al. detected anti-HCV in $24 \%$ of patients with urticaria [21].

The current study showed that $7.6 \%$ and $11.8 \%$ of untreated and treated patients respectively had lichen planus. It is believed that lichen planus may be exacerbated by interferon treatment for $\mathrm{HCV}$ but sustained viral response may alleviate the symptoms of lichen planus [25]. This is in agreement with Asaad and Samdani who found that there is a high prevalence of HCV infection was detected in patients with lichen planus [26]. In contrast, a study conducted in an Indian population by Patil et al. showed no evidence of HCV infection in patients with oral lichen planus [27]. However, it is estimated that $10-40 \%$ of patients with lichen planus are positive for $\mathrm{HCV}$ infection [28].

The mechanism that links lichen planus and $\mathrm{HCV}$ infection remains unclear, but could be due to an aberrant immunologic response or probably related to viral replication in lymphocytes [29]. Lazaro et al. demonstrated that $\mathrm{HCV}$ infects keratinocytes from cutaneous lichen planus lesions and the viral RNA is translated in these cells as demonstrated by the HCV incorporated in the skin biopsies [30]. In addition, the presence of increased frequency of HCV among LP patients has put lichen planus as one of the skin disorders associated with chronic HCV infection [31].

In our study we found that Pruritus, hair falling, vasculitis, oral lichen planus, alopecia and purpura occur more frequently in patients with severe viraemia which is concordant with Raslan et al. who found that some skin manifestations were significantly frequent in patients with severe viremia as vasculitis, purpura, lichen planus, pruritus and alopecia [4]. Direct infection of $\mathrm{HCV}$ in the skin, lymphocytes, endric antigenpresenting cells, and blood vessels is a known cause of extrahepatic manifestations. However, this is not always the cause as immune mediated pathogenesis and skin responses secondary to other organ affected by HCV like liver and thyroid are other causal mechanisms [32].

$\mathrm{HCV}$ infection is the most common condition associated with mixed cryoglobulinemia. Almost half of patients with chronic hepatitis $\mathrm{C}$ have mixed cryoglobulinemia and up to $90 \%$ of 
patients with essential mixed cryoglobuinemia have evidence of HCV infection. Therefore, all patients with cryoglobulinemias should be screened for $\mathrm{HCV}$ infection. Conversely, HCV patients with progressive and worsening cutaneous involvement should be tested for cryoglobulinemia [33].

In this study, cryoglobulinemia was positive in $45 \%$ of all patients. In contrast, a Pakistani study found only $3 \%$ positivity of cryoglobuinemia in chronic HCV patients [9]. This difference could be due to: firstly; HCV related factors, particularly genotype [34,35]. Secondly; MC shows higher incidence in patients with hepatic cirrhosis and later stages of fibrosis [36]. Thirdly; different cryoglobulins detection methods from one study to another and difficult detection of cryoglobulins because of their thermolability might cause heterogeneity in the prevalence results between studies. Finally, there are environmental and/or host genetic factors that might contribute to the pathogenesis of mixed cryoglobulinemia [37].

In our study, the most frequent skin manifestations associated with cryopositivity in untreated patients were; purpura (100\%), pruritus (67\%) and vasculitis (60\%). The three most common symptoms of patients with mixed cryoglobulinemia are palpable purpura, arthralgia, and weakness, which were named as the core symptoms of cryoglobulinemia [38]. The intravascular precipitation of immunoglobulins in lower temperatures causes reversible mechanical obstruction in the small vessels of skin and immune-complex mediated vasculitis and chronic ulcers may also occur [39]. The obstructive immune complexes may also cause pruritus and urticaria [40].

In treated group, there was no any patient with vasculitic lesions. This may be due to the effect of treatment of antiviral therapy against HCV which is the mainstay of treatment for cryoglobulinemic disorders associated with HCV infection. There is good evidence that treatment leads to reduction of cryoglobulins, improve cutaneous vasculitis and rashes [33].

Limitations of our study were that patients included in this study received treatment with peg-interferon plus ribavirin before the year 2015 and it did not include cases treated by Direct Acting Antivirals (DAAs). This was simply because by the time this study was carried outwe did not find cases with skin lesions related to DAAs but we found cases with skin lesions previously treated with interferon, so further studies are needed to rule out relation between DAAs and skin lesions in HCV patients.

\section{CONCLUSION}

Skin manifestations are present in $61 \%$ of chronic $\mathrm{HCV}$ patients and less frequent in treated group. The frequency of skin maniestations increases with the advancement of Child-Pugh class. Pruritis is the most frequent manifestation in all patients and more frequent in treated group. Alopecia is frequent in treated than untreated patients.

With sever viremia; pruritis, hair falling, vasculitis, oral lichen planus, alopecia and purpura are frequent skin manifestations. Purpura, pruritus and vasculitis are frequently associated with cryoglobulinemia.

Research ethics considerations: The protocol of this study was reviewed and approved by Zagazig University ethical committee. Written and informed consent was obtained from all participants.

\section{Conflict of interest: No \\ Funding: NO}

\section{Acknowledgment}

The authors would thank all colleagues who helped in conducting this study.

\section{REFERENCES}

1. Ramos-Casals M, Loustaud-Ratti V, De Vita S, Zeher M, Bosch JA, Toussirot E, et al. SS-HCV Study Group Sjögren syndrome associated with hepatitis C virus: a multicenter analysis of 137 cases. Medicine 2005; (84):81-89.

2. Cacoub P, Renou C, Rosenthal E, Cohen P, Loury I, Loustaud-Ratti V, et al. Extrahepatic manifestations associated with hepatitis $\mathrm{C}$ virus infection. A prospective multicenter study of 321 patients. Medicine 2000; (79):47-56.

3. Cacoub P, Saadoun D, Limal N, Sene D, Lidove $\mathrm{O}$, Piette JC. Pegylated interferon alfa- $2 b$ and ribavirin treatment in patients with hepatitis $\mathrm{C}$ virus-related systemic vasculitis. Arthritis Rheum 2005; (52): 911-915.

4. Raslan HM, Ezzat WM, Abd El Hamid MF, Emam H, Amre KS. Skin manifestations of chronic hepatitis $\mathrm{C}$ virus infection in Cairo, Egypt. East Mediterr Health J 2009; (15): 692-700. 
5. Fachinelli L R, Silva E C, Figueiredo M G, Possa MS, Pelegrinelli FF, Molina RJ. Hepatitis C and cutaneous alterations. Rev. Soc. Bras. Med. Trop 2012; 45(6): 770-773.

6. Akhtar E, Manne V, Saab S. Cirrhosis regression in hepatitis $\mathrm{C}$ patients with sustained virological response after antiviral therapy, a meta-analysis. Liver Int 2015; 35(1): 30-36.

7. Handler N. S, Handler M. Z, Stephany M. P, Handler GA, Schwartz RA. Porphyria cutanea tarda: an intriguing genetic disease and marker. Int J Dermatol 2017; 56(6):e106-e107.

8. Veluru C, Atluri D, Chadalavada R, Elke Burns, Kevin D. Mullen. Skin rash during chronic hepatitis C therapy. Gastroenterol Hepatolo 2010; 6(5): 323-325.

9. Asim S, Wahid Z. Cutaneous Manifestations in Hepatitis C virus infection. Pak J Med Sci 2012; 28(5):891-894.

10. Ali M, Rehman IU, Idrees M. Emergence of genetically variant hepatitis $\mathrm{C}$ virus population in response to increased antiviral drug pressure, Pakistan. Virus Genes 2014; (48):543-549.

11. Morsy M, Al-Bayoumi Y, Ahmed EF. Cutaneous manifestations in chronic hepatitis $\mathrm{C}$ patients: Aprospective study from Egypt. Gulf J Dermatol Venereol 2011; 18(2):27-32.

12. Soylu SL, Gül U, Kiliç A. Cutaneous manifestations in patients positive for anti-hepatitis $\mathrm{C}$ virus antibodies. Acta Derm Venereol 2007; (87): 49-53.

13. Abbas S, Altaf A, Saleem N, Muzaffar R. High prevalence of HIV infection among injection drug users (IDUs) in Hyderabad and Sukkur, Pakistan. J Pak Med Assoc 2009; (59):136-140.

14. Van Riet E, Hartgers FC, Yazdanbakhsh M. Chronic helminth infections induce immunomodulation: consequences and mechanisms. Immunobiology 2007 ;( 212):475-490.

15. Berk D. R, Mallory S. B, Keeffe E. B, Ahmed A. Dermatologic disorders associated with chronic hepatitis C, effect of interferon therapy. Clin Gastroenterol and Hepatol 2007; 5(2): 142-151.

16. Sayiner M, Golabi P, Farhat F, Younossi ZM. Dermatologic manifestations of chronic hepatitis C infection. Clinics in Liver Disease 2017; 21(3): 555-564.

17. Agesta N, Zabala R, Díaz-Pérez J L. Alopecia areata during Interferon Alpha-2b/Ribavirin Therapy. Dermatology 2002; (205):300-301.

18. Goh C. Hepatitis C treatment and alopecia totalis. J Investig Dermatol Symp Proc 2013; 16 (1): S59-S60.
19. Gamal N, Brodosi L, Misciali C, Patrizi A, Vukatana G, Malavolta N. Alopecia universalis after discontinuation of pegylated interferon and ribavirin combination therapy for hepatitis $\mathrm{C}$ : acase report. Ann Hepatol 2014; 13(2):293-296.

20. Siddique N, Pereira BN, Hasan Arshad S. Hepatitis $\mathrm{C}$ and urticaria: cause and effect? Allergy 2004; (59): 668-672.

21. Kanazawa K, Yaoita H, Tsuda F, Okamoto H. Hepatitis $\mathrm{C}$ virus infection in patients with urticaria. J Am Acad Dermatol 1996; (35): 195-198.

22. Llanos F, Raison-Peyron N, Meunier L, Ducos J, Meynadier J. Hepatitis $\mathrm{C}$ virus infection in patients with urticaria. J Am Acad Dermatol 1998; (38): 646.

23. Smith R, Caul EO, Burton JL. Urticaria and hepatitis C. Br J. Dermatol 1997; (136): 980.

24. Dega H, Francès C, Dupin N, Lebre C, Simantov A, Callot C. Pruritus and the hepatitis $\mathrm{C}$ virus. The MULTIVIRC Unit. Ann Dermatol Venereol 1998; (125): 9-12.

25. Magbri A. Skin manifestations of hepatitis C in chronic renal disease patient. Acta Physiologica 2017; 3 (3: 14): 2469-6676.

26. Asaad T, Samdani AJ. Association of lichen planus with hepatitis C virus infection. Ann Saudi Med 2005; (25): 243-246.

27. Patil S, Khandelwal S, Rahman F, Kaswan S, Tipu S. Epidemiological relationship of oral lichen planus to hepatitis $\mathrm{C}$ virus in an Indian population. Oral Health Dent Manag 2012; (11): 199-205.

28. Gumber SC, Chopra S. Hepatitis C: a multifaceted disease. Review of extrahepatic manifestations. Ann Intern Med 1995; 123(8): 615-20.

29. Harman M, Akdeniz S, Dursun M, Akpolat N, Atmaca S. Lichen planus and Hepatitis $\mathrm{C}$ virus infection: an epidemiologic study. Int $J$ Clin Pract 2004; 58: 1118-1119.

30. Lazaro P, Olalquiaga J, Bartolomé J, OrtizMovilla N, Rodríguez-Iñigo E, Pardo $\mathrm{M}$. Detection of hepatitis Virus RNA and core protein in keratinocytes from patients with cutaneous lichen planus and chronic hepatitis C. $J$ Invest Dermatol 2002; 119: 798-803.

31. Mignogna MD, Lo Muzio L, Lo Russo L, Fedele S, Ruoppo E, Bucci E. Oral lichen planus: different clinical features in $\mathrm{HCV}$ - positive and HCV-negative patients. Int J Dermatol 2000; (39): 134-139.

32. Schwartz RA (2017): Cutaneous manifestations of hepatitis C. https://emedicine.medscape.com/ article/1134161-overview\#a5

Amer et al., Afro-Egypt J Infect Endem Dis 2019; 9(1): 58-66

https://aeji.journals.ekb.eg/

http://mis.zu.edu.eg/ajied/home.aspx 
33. Dharel N (2017): Cryoglobulinemia (Hepatitis C). http://www.clinicaladvisor.com/hospitalmedicine/cryoglobulinemia-hepatitisc/article/604566/

34. Ray S. C, Arthur R. R, Carelz A, Bukh J, Thomas DL. Genetic epidemiology of hepatitis $\mathrm{C}$ virus throughout Egypt. J Infecti Dis 2000; 182 (3): 698-707.

35. Messina J. P, Humphreys I, Flaxman A, Brown A, Cooke GS, Pybus OG.: Global distribution and prevalence of hepatitis $\mathrm{C}$ virus genotypes. Hepatol 2015; 6 (1): 77-87.

36. Ramos-Casals M, Stone J. H, Cid M. C, Bosch X. The cryoglobulinaemias. The Lancet 2012; 379 (9813): 348-360.
37. Lauletta G, Russi S, Conteduca V, Sansonno L. Hepatitis $\mathrm{C}$ virus infection and mixed cryoglobulinemia. Clin Dev Immunol 2012: 1-11.

38. Meltzer M, Franklin EC Cryoglobulinemia: a study of twenty nine patients. I. IgG and IgM cryoglobulins and factors affecting cryoprecipitability. Am J Med 1966; (40): 828-836.

39. Cacoub P, Gragnani L, Comarmond C, Zignego AL. Extrahepatic manifestations of chronic hepatitis C virus infection. Dig Liver Dis 2014; 46(Suppl 5):S165-173.

40. Dupin N, Chosidow O, Lunel F, Cacoub P, Musset L, Cresta P. Essential mixed cryoglobulinemia.A comparative study of dermatologic manifestations in patients infected or non infected with hepatitis C virus. Arch Dermatol 1995 ;( 131):1124-1127. 